\title{
Disaster management in libraries: the role of a disaster plan
}

\author{
G. Morgan \\ University of Cape Town Libraries, Private Bag, Rondebosch, 7700 Republic of South Africa \\ gm@vctlib.uct.ac.za
}

J.G. Smith*

School of Librarianship, University of Cape Town, Private Bag, Rondebosch, 7700 Republic of South Africa

jgs@education.uct.ac.za

\begin{abstract}
It is contended that disaster management and planning should be one of the most important aspects of library management, but in practice it has been found to be a neglected field in librarianship, particularly in South Africa. This article explores the main disaster management issues and reports on a study that investigated disaster planning in research, academic and public libraries in the Greater Cape Metropolitan Area. It was found that the majority of the libraries investigated were lacking in formal disaster plans and were generally under-prepared for any potential disasters which may occur. This was attributed to inadequate resources and also to the apathetic attitude of library staff. The authors suggest that it is important that all libraries institute disaster management procedures and a formal disaster plan as this would assist in preventing disasters. Such a plan further provides step-by-step instructions that help to eliminate panic, it ensures that proper decisions are taken, it reduces damage to collections and limits recovery costs should a disaster occur. A framework for a model disaster plan is therefore proposed to serve as a guideline for libraries in the development of disaster plans.
\end{abstract}

Daar word aangevoer dat noodbestuur en sodanige beplanning een van die mees belangrike aspekte van biblioteekbestuur behoort te wees, maar in die praktyk is gevind dat dit in Suid-Afrika 'n verwaarloosde terrein is. Die vernaamste aspek omtrent noodbestuur word ondersoek, en navorsing wat noodbeplanning in akademiese, navorsings- en openbare biblioteke ondersoek het in die groter Kaapse Metrpolitaanse Gebied word bespreek. Die meerderheid biblioteke wat ondersoek is, het tekortkominge getoon in hul formele noodplanne en hulle was oor die algemeen onvoorbereid op potensiële rampe. Dit word toegeskryf aan onvoldoende hulpbronne asook die apatiese houding van die biblioteekpersoneel. Die skrywers stel voor dat dit belangrik is dat alle biblioteke noodbestuurprosedures in 'n formele noodplan moet formuleer en daarstel, aangesien dit sal bydra om rampe te voorkom. So 'n noodplan verskaf stap-vir-stap-instruksies om paniek te elimineer en te verseker dat behoorlike besluite geneem word. Dit verminder ook die beskadiging van versamelings en beperk herstelkostes as 'n ramp sou plaasvind. 'n Raamwerk vir 'n modelnoodplan word voorgestel om as voorbeeld te dien vir biblioteke in die ontwikkeling van noodplanne.

*Author to whom correspondence should be addressed.

Library resources are very valuable, either for the information that they contain, or for their physical beauty. Thus, because of their nature, they are particularly susceptible to disasters such as fires or floods. As Parsons (1952:273) has aptly stated in his account of the destruction of the library at Alexandria some 2000 years ago:

'The brittle and frail paper of Egypt and even tougher skins of Pergamon seem fragile media indeed on which to confide the precious knowledge and wisdom of the ages. Ready victim of the accidents of nature, fire, water and the other elemental forces ... the book would appear to have small chance of survival'.

Many of our libraries house and protect valuable material and a disaster, such as a fire or a flood, could be devastating in terms of loss of assets, services and the cost to repair the damage incurred. It is, therefore imperative that disaster management should form an essential part of the management function of a library. Disaster management, however, has traditionally been a neglected field in librarianship, and this has been exacerbated by severe budget cuts during the last few decades, which have led to enormous shortages of financial and staff resources. While there has been an increase in disaster management research in Britain and America during the 1980s and 1990s, it is still a sorely neglected field in South Africa. There is thus a general paucity of studies on disaster management in libraries in South Africa.

Disaster recovery can be a long and very expensive process, during which service to the users can be negatively affected. It is, therefore, essential to be prepared for disasters to minimize the consequences should a disaster occur. The development of a comprehensive disaster plan is thus, a fundamental requirement as it eliminates panic, it ensures that logical and appropriate decisions are taken in times of disaster, which in turn will reduce potential damage.

This article explores the main disaster management and planning issues and utilizes data derived from an exploratory study conducted by the primary author on disaster management and planning in the Western Cape region, as well as information derived from the literature. A model disaster plan is developed and it is hoped that the stimulus will be provided for the development of disaster plans in libraries, where such a lacunae exists.

\section{Main concepts in disaster management}

A disaster has been defined as 'an adverse or unfortunate event, a great and sudden misfortune, [a] calamity' 
(Chambers twentieth century dictionary, 1990) and according to Harrison (1979:7) 'a disaster is what happens only if you are not prepared for it'.

Disasters in the library context can be either natural or manmade. Natural disasters are generally induced by such events as floods, fires, earthquakes, storms (a combination of wind and rain), cyclones and hurricanes. Man-made disasters include destruction during war-time, threats emanating from social or political unrest, such as bombings or rioting, and, malicious vandalism or arson. Power failures and power surges can further cause extensive damage to computer files. Man-made disasters can further also arise from human error and negligence and not only from a deliberate intent to do harm. Whatever, the source of the disaster, the destruction and devastation it causes threatens the safety of the materials housed by the library, and it disrupts the provision of library services.

Anderson and McIntyre (1985:9) refer to a disaster that affects libraries as

'an unexpected event with destructive consequences

to their holdings. It can be a small-scale incident or a

full blown emergency, but in either case it requires

prompt action to limit damage'.

It is thus clear that a disaster can be all-encompassing and catastrophic, or it may be smaller with a more localized effect. However, whatever the magnitude of the disaster, the repercussion for libraries remain serious. Smaller incidents generally occur far more frequently than major disasters. It is thus to be expected that most librarians will be involved in at least one disaster (albeit of varying magnitudes) during their professional career, and yet this possibility is very rarely recognized or acknowledged. (Harvey, 1993b:119).

Disaster management in libraries involves the development of a disaster plan, which can be described as a set of rehearsed actions, which will reduce the likelihood of a disaster occurring and further also reduce the extent of the damage, should a disaster occur. Another aspect is the development of recovery procedures that outline the steps that should be followed to restore damaged items (Harvey, 1993a:221). While library disasters have been an all too common occurrence throughout history, disaster management and planning is a relatively new concept. The related issues of preservation and conservation have, in contrast, been reasonably well addressed by libraries since the last century.

It is a logical assumption that disaster prevention is preferable to the costly and lengthy process of post-disaster recovery. Every effort should therefore be made to prevent a disaster from occurring. This requires that buildings be properly constructed, well maintained and that staff are well trained in disaster prevention (Harvey, 1993a:221). However, while it is necessary to take all the necessary precautions to lessen the likelihood of a disaster occurring, it is important to realize that not all disasters can be prevented. McIntyre (1988:42), therefore, stresses that disaster plans should have two essential aims: prevention and preparedness. It is important to do everything that is necessary to prevent a disaster from occurring, but, should one occur, it is equally as important to handle it efficiently and swiftly to minimize the damage.

It is a sine qua non that the safety of people in libraries, that is the staff and users, is of paramount importance, and should thus be the first consideration in the event of an emergency occurring. The assumption is therefore made that in the event of a disaster occurring, the safety of all occupants of the library would have been assured and if necessary occupants would be evacuated from the premises. This article will therefore concentrate on disaster management and planning issues that relate to library materials and buildings only.

\section{Library disasters over the ages}

One of the most devastating disasters in library history, occurred in the 3rd century AD, when a fire demolished the library at Alexandria. In more recent times, there have been other major library disasters. In 1966, the Arno River in Florence burst its banks and caused catastrophic flooding of the Bibliotheca Nazionale Centrale, where one million volumes were damaged by the intrusion of the muddy river water. (Fortson, 1992:vii). This disaster acted as a catalyst in precipitating an increase in disaster management research and paper restoration. Many experts in paper conservation from around the world offered to participate in the restoration effort and it further increased awareness in library preparedness and led to the development of techniques and procedures for the treatment of water damaged materials (Harvey, 1993b:20).

There have been many other disasters, however, particularly in the last few decades. Fires occurred at the Jewish Theological Seminary Library in 1966, the Klein Law Library at Temple University, Philadelphia in 1972, and in 1985, lightning caused a fire, which subsequently destroyed 60000 items at the Dalhousie Law School in Nova Scotia (Fortson, 1992:vii). In 1986 the Los Angeles Central Public Library was destroyed in a fire started by arsonists, and in 1988 a fire at the USSR Academy of Sciences Library, caused by defective wiring, destroyed approximately 400000 items and one quarter of a very valuable newspaper collection (Harvey, 1993a:221). Flooding occurred at the Corning Museum and Library in 1972 and flooding also caused construction-related water damage at Stanford's Meyer Library in 1978 .

While fire and flood disasters are the most prevalent, other factors also cause destruction. A hurricane resulted in damage at the University of Corpus Christi in 1970 (Fortson, 1992:vii). The San Fransisco earthquakes in 1989 deposited books on the floor in various libraries, including the Los Angeles Public Library and Stanford University Library. Political unrest can also result in library disasters. The Rumanian State Central Library was destroyed in December 1989, during the overthrow of the Ceaucescu government. In more recent times, many libraries in Kuwait were completely destroyed during the Gulf War. However, not all library 
disasters are so all-encompassing and devastating. Many lesser disasters have also occurred (Harvey, 1993b:121).

The numerous library disasters which have occurred since the Florence flood, have led to research and development in techniques and the promotion of the need for disaster plans. It was, however, not until the late 1970s that the principle was accepted that disaster planning should form an integral part of the management function of libraries (Harvey, 1993b:1920,121). Although this principle has been accepted in theory, in practice, however, it is often still neglected, partly as a result of severe budget cuts during the 1990s, which have led to enormous shortages of financial and staff resources.

\section{Disaster planning}

All too often the assumption is made that a disaster will never happen, or alternatively, if accepted that it may occur, that the insurance will cover the costs to recoup all losses. These are dangerous assumptions and it is safe to say that many people are taken by surprise when a disaster does occur and are uncertain how to handle the situation. The situation is further compounded by the fact that many people ignore warnings to alert them of an impending disaster (Wright, 1979:254). Disasters are often further exacerbated by human error and neglect, or even solely caused by such negligence (Griffith, 1983:258).

Numerous accounts of library disasters that range from fires to floods to pest infestation have appeared in the literature (cf. Buchanan, 1979; Burgess, 1989; DeCandido, 1988; Harrison, 1979; Olson, 1986; Schmelzer, 1968; Strong, 1987; Sung et al., 1990; Watson, 1989). Two aspects are a recurring theme of these reports: first, negligence and a lack of building maintenance often contribute to the occurrence of library disasters; and second, library disaster recovery is a time consuming and very expensive process that should be avoided if at all possible. It is thus imperative that libraries should apply preventative measures and establish emergency procedures to prevent and/or diminish the impact should a disaster happen (McIntyre, 1988:42; 1989:1). The development of an efficient disaster plan that encapsulates and codifies all preventative and emergency procedures is thus essential to limit the incidence of disasters and to ensure swift and efficient reaction should one occur.

A number of authorities have suggested that disaster planning consists of the following four phases: prevention; preparedness; reaction; and recovery. These four phases have been discussed in detail by Anderson and McIntyre, 1985; Bohem, 1979; Coates, 1987; Fortson, 1992; Harvey, 1993a; 1993b; Griffith, 1983; McIntyre, 1988; 1989; Thorburn, 1993; and Watts, 1993.

The prevention stage aims to identify the risks posed by the library building itself, as well as the equipment and fittings contained in the building and to minimize the potential damage in the event of a disaster. The major risks to identify are unauthorized access, fire and flooding. A safe and well designed building will reduce the likelihood of a disaster occurring. The building should be conducive to easy and swift evacuation and emergency exits should be well placed. The structural design of the building should be sound, and there should be regular building maintenance inspections. The roofs should be well pitched and without leaks, leakages in general should be prevented, water pipes and electric wiring should be well positioned and maintained, and they should not be lead through main storage areas. Faulty electric wiring is one of the major causes of fires in buildings. It is thus important that there are effective fire and water detection/alarm systems, as well as fire suppression systems in libraries. Valuable materials should not be stored in basements or on top floors. In short, good building maintenance is crucial (Ashman, 1995:9; Coates, 1987:52-55; Fortson, 1992:8).

The preparedness phase is based on the premise that not all disasters can be prevented, and it involves planning and preparing to deal with disasters should they arise. It includes drawing up a disaster plan and forming a disaster reaction team, with a leader. The disaster plan and the list of team members with their home telephone numbers should be clearly posted in the library. Disaster plans should further be circulated amongst the staff and workshops and disaster drills should be carried out. Insurance contracts are a very important aspects of the preparedness phase. It is thus essential that inventories are up-to-date and that back-ups are made of the shelflist or catalogue to assist with insurance claims should a disaster occur. Another aspect of preparedness is the availability of disaster supplies and equipment, which should be placed in strategic places and always be ready and available for use. The library should also be in contact with and cooperate with emergency services such as the fire brigade and the police (Coates, 1987:56-60; Harvey, 1993a:230-231; 1993b:127-129; Watts, 1993:5).

The reaction phase refers to the steps that should be taken when disaster does strike. The first step is to contact the disaster team and its leader and the appropriate emergency services. The stability of the building must be ascertained by a professional before the building is entered to assess the damage. Protective clothing should be worn, as disaster sites can present a health hazard, such as that caused by leaking sewerage pipes. After the safety of all persons in the library has been ensured, the library materials should be evacuated as soon as possible. However, care should be taken that the whole operation is well organized and controlled, or else chaos could reign. The handling of materials must be done with care as they can be further damaged at this stage by inexperienced helpers. The evacuation of materials should take place according to previously established priority lists. Damaged materials should be treated as soon as possible and those that can be restored on site should be separated from those that have to be transported to external restoration facilities. The rapid institution of recovery measures is of the utmost importance as delay can cause further damage, such as mould setting in (Donnelly, 1993:11; Harvey, 1993a:231234; Harvey, 1993b:129-131; McIntyre, 1988:44; McIntyre, 1989:6-7; Thorburn, 1993:76-78; Watts, 1993:5). 
The aim of the recovery phase is to re-establish normal working conditions and to resume service to the users as soon as possible. This phase further involves repairing and restoring those library materials damaged in the disaster. If water damage has occurred, this may include air-drying on the library's premises or at another location, or, it may involve freeze-drying or vacuum-drying or using the New Soviet drying technique at special facilities at another location (Sung et al., 1990:309). The recovery of fire damaged materials is more difficult, as once material is burnt, the image may be very difficult to reproduce or restore to its original condition, depending on the degree of the damage. Such recovery requires skill and expensive equipment. Furthermore, materials damaged in a fire suffer not only fire damage, but also water damage as a result of the water used to douse the fire (Thorburn, 1993:76-78).

While the materials are being treated and restored, the library itself also has to be cleaned up. In the case of a flood, there may be extensive water damage and the interior will need both drying out and restoration. In the case of a fire there will be considerable damage that will include both charring and water damage. Hardware and furniture may have to be replaced. The insurance assessment and claim will have to be finalized, and the building may also need structural renovations, depending on the severity of the disaster. In the case of large scale water intrusion, the library will have to be monitored for mould growth. As it is essential to re-establish library services to users as soon as possible the library might have to operate from a temporary location while repairs are being done. Once normal conditions have been re-established, the disaster plan should be evaluated to determine its effectiveness and any inadequacies should be rectified (Fortson, 1992; Griffith, 1983:261-265; Harvey, 1993a:131-132; McIntyre, 1988:46; Watts, 1993:5).

The disaster management of computerized material is becoming an increasingly essential aspect of disaster planning, as a large number of library catalogues, issue and other subsystems are now computerized. The most fundamental precaution with regard to computerized disaster planning and prevention is to create regular back-ups of such information. The back-up tapes should be stored at a separate location. It is also important to insure the computer hardware and to provide the correct conditions for the location of the computers. The room temperature and humidity should be kept as constant as possible and the electric wiring should be well maintained and all safety specifications adhered to (Alegbeleye, 1993:61-65).

An important aspect of disaster planning is insurance. A library's insurance needs vary according to the size of the library, the nature of the potential risks, the nature of the collection, and, the finance available. Each library has to decide on the type of insurance, what is to be insured and the value of the insurance. It is important that the conditions of the insurance be included in a disaster plan (Kahn, 1994:23; Morris, 1986:93-94).
Disaster planning, as such, generally does not address the safety of people in libraries. Such safety procedures are of paramount importance and are normally developed in conjunction with emergency services, such as the ambulance services or the fire brigade and are handled as a very critical, but separate, issue with its own documentation. Disaster planning follows on from these procedures, and assumes that the safety of people has been assured and concentrates on the protection and rescue of the library building and its materials (Harvey, 1993b:122).

\section{Disaster plan}

Watts (1993:5), is of the opinion that disasters are inevitable and thus all libraries should be prepared when they happen. A well conceptualized and carefully formulated disaster plan could in many instances prevent a disaster from occurring, or at least assist in minimizing the damage to buildings and materials should a disaster occur. Such a plan would ensure that a risk assessment is done to establish security measures, that reaction is swift should a disaster occur, and it would institute procedures to salvage damaged materials as quickly as possible after the event. It is thus important to convince management of the necessity for such a plan (McIntyre, 1988: 43; 1989:2).

In summary, it could be stated that the main objectives for introducing such a plan are to

- anticipate possible disasters and to introduce measures to reduce the effects should it occur and thus minimize damage,

- ensure that staff are informed and trained in disaster procedures,

- ensure frequent inspection of the building by trained professionals,

- ensure that procedures are well planned and disaster supplies and equipment are at hand and readily available,

- establish contact with emergency services and ensure that they are familiar with the nature of the library, its collections and disaster procedures,

- ensure that normal conditions and library services are reestablished as soon as possible after an emergency, and

- ensure that feed-back mechanisms are introduced after a disaster has occurred to evaluate the effectiveness of the disaster plan (Fortson, 1992:77-82; Harvey, 1993b:122).

The procedure for developing a disaster plan depends on the size of the library, the number of staff and whether any additional funding is available to hire a consultant to assist in the planning process. The library should assume responsibility for the disaster plan and it should be adapted to suit local conditions. Thus the risks which are specific to each institution or area should be evaluated and incorporated in that institution's disaster plan (Buchanan, 1988:105). As many staff as possible should be involved in the development of a disaster plan to increase general awareness among the library staff of disaster procedures and the potential devastating effects of disasters. There should, ideally, also be 
a staff member who is responsible for the library's disaster planning (Fortson, 1992:77-82; Harvey, 1993b:123).

Such a disaster plan should preferably be a formal, written document, and it should incorporate all the procedures to be followed with regard to the four phases of disaster management, namely: prevention, preparedness, reaction and recovery (Alegbeleye, 1993:94-96). The essential elements of a disaster plan would include a detailed description of the building and the collections, an outline of disaster prevention procedures and recovery techniques, a statement regarding the availability of outside help and an outline of the decisionmaking structure in the event of a disaster. The plan must be kept current and up-to-date and all staff must be familiar with the disaster procedures. The disaster plan may involve cooperative arrangements with other libraries or external organizations. To ensure that the plan is effective and to isolate problems, the disaster plan should be tested in the form of a simulation exercise (Nance, 1993:64-66).

\section{South African situation}

The nature of potential disasters are often determined by the geographical area and region of the world in which the library is situated. However, the two most common natural disasters, fire and flood, are not necessarily limited to specific geographical areas. Even in areas that are particularly dry, flash floods do occur, which can lead to flooding.

South Africa's wide climatic diversity make it particularly susceptible to disasters such as fire and flood, and the excessive humidity in certain areas can lead to the development of mould and insect infestation. Flood and fire, however, are the two greatest potential threats in South Africa. The higher rainfall areas in the country, such as the Western Cape, KwaZulu/Natal and areas of Mpumalanga are particularly susceptible to flooding (South African Official Yearbook, 1992:4), but flash floods frequently occur in many other areas as well. The severe rain storms that South Africa experiences can further cause severe water and wind damage.

Large parts of the country are arid or frequently subjected to protracted periods of drought which increases the fire hazard potential. Certain areas of South Africa are also prone to electric storms which hold a singular threat as they are characterized by lightning and heavy rains. Lightning is very hazardous as it can ignite fires and libraries in these areas should be particularly aware of this danger. South Africa is fortunately not prone to earthquakes, as this country is not situated on any of the world's major earthquake belts. Earth tremors occur, but they are minor and very rare. South Africa is also not prone to cyclones, hurricanes or tornadoes.

Any country which experiences periods of political or social unrest, is prone to destruction of buildings and property, because of rioting, bombings and so forth. Some countries are more susceptible to such forms of destruction than others. South Africa has a history of political instability and such threats have been a very real danger. Malicious vandalism, which is prevalent throughout the world, should always be considered a potential threat.
Disaster management and the contiguous field of conservation and preservation in South Africa has been sadly neglected and continues to be so. Coates (1993:9) believes that the unstable political situation and the economic recession have contributed towards this neglect. Coates (1993: 1011) reports that, according to a national survey which included national, university and public libraries, only $58 \%$ of the respondents had a clear preservation policy. The remainder react in an ad-hoc way to crises. Very few of the respondents had a disaster plan, even though the South African Library has actively been promoting disaster preparedness.

According to the National Libraries Act of 1985, the South African Library has a duty to provide a national restoration service. However, there is no provision in the state subsidy to provide the funding to fulfil this duty. On the whole, the funding for preservation and conservation in this country derives from donations and sacrifices made from elsewhere in library budgets.

\section{Exploratory survey of disaster management in the Western Cape}

A survey was conducted by the principal author to explore and evaluate the present situation regarding disaster management and planning in the Greater Cape Metropolitan Area. Twelve research/academic and public libraries in the above region were polled. A purposive sample was drawn to include the six major academic/research libraries, the independent municipal public library service and the five largest public libraries affiliated to the Western Cape Provincial Library Service in the study area. Mailed questionnaires were used as the primary data collection method, while interviews were employed to supplement and clarify information gained from the questionnaires.

The results from the study showed that the situation in the Greater Cape Metropolitan Area varied considerably from library to library. An overview of the main findings with regard to the four phases of disaster management and planning, namely prevention, preparedness, reaction and recovery, in the libraries in the Greater Cape Metropolitan Area will be outlined in the following paragraphs.

The prevention phase is concerned with preventing a disaster from occurring. This is mainly achieved by ensuring that buildings are well designed and maintained. The most important aspects that should be considered are that the building should be structurally sound, roofs should be well maintained, there should be no leakages, underground water must be monitored, and, electric wiring should be kept in good condition. The data collected showed that $83 \%$ of the libraries surveyed conducted building maintenance inspections. However, only $40 \%$ of these libraries inspected their buildings more frequently than once a year.

The preparedness and reaction phases involve being prepared for a disaster, should one occur, and are mainly concerned with the institution of a well-developed disaster plan. Only $42 \%$ of the libraries surveyed had formal disaster plans, 
$17 \%$ had informal arrangements with emergency services to assist in the event of a disaster, and $42 \%$ had no disaster plans at all. Those libraries that had formal disaster plans were well prepared and organized and their disaster plans were relatively comprehensive. Their plans were updated or revised either regularly or on an ad-hoc basis, and the staff members were aware of disaster routines. In most instances a specific staff member was designated as the person responsible for disaster planning. The disasters (both natural and man-made), that were catered for, were in keeping with the risks relevant to each institution and each area.

The informal disaster plans that were in place in $17 \%$ of the libraries surveyed, mainly comprised arrangements with local emergency service providers, such as the Fire Brigade and the Police, and, in one case, the Campus Protection Services. It is suggested, however, that while informal disaster plans are better than none, they are still inadequate. Formal disaster plans serve to make staff aware of potential dangers, and they formalize routine emergency procedures, such as evacuation drills.

All the libraries with formal disaster plans had co-operative disaster arrangements with external service providers such as emergency services, that is the fire brigade, and/or outside contractors to provide for example freeze and freeze-drying facilities. The libraries, which did not have any disaster plans, did not have co-operative emergency arrangements with external service providers, while those that had informal plans, did have arrangements with emergency service providers, such as the Fire Brigade and the Police. Emergency arrangements with external service providers and outside contractors, it is suggested, are among the most fundamental aspects of disaster planning. It is further suggested that access to such facilities can be shared to reduce financial outlay.

Providing standardized procedures to back-up computer data on a daily basis is another important aspect of disaster management and planning. It is essential that computerized catalogue, issue and other information be safeguarded against total obliteration should any disaster affect the computer system. The vast majority (75\%) of the libraries included in the survey were computerized and the survey indicated that all of these libraries carried out regular back-up procedures. The seriousness of potential loss of data has obviously prompted even those libraries without any other disaster prevention plans to implement preventative measures to ensure that they do not lose their computerized data.

Of the libraries surveyed, 50\% had emergency evacuation and/or disaster drill procedures. Another library was in the process of developing such a plan, while the remaining $42 \%$ of the libraries never implemented routine emergency drill procedures. This is a very important aspect, as it helps to make the staff aware of disaster routines. Of the five libraries with formal disaster plans, four regularly held emergency drills, and one was in the process of developing such procedures. It would thus appear that this very important aspect of disaster management was particularly well catered for by those libraries that had formal disaster plans, and generally neglected by the libraries without formal disaster plans.

Adequate insurance coverage ensures that a library will be able to fully, or at least partially, recoup its losses should a disaster occur. As all twelve libraries had disaster insurance it would, thus, appear that this aspect of disaster management was taken seriously by all concerned. However, while all the libraries insured their buildings and fixed assets such as furniture and computer hardware, the practices with regard to library stock, computer software, and data files, varied considerably. The disaster insurance for library stock is very expensive and this is compounded by the difficulties to ascertain the replacement value of such assets. Many libraries, thus, prefer to carry the cost of damage recovery themselves should a disaster occur. The authors contend that the wisdom of such a decision is highly contentious.

The recovery phase in disaster management involves restoring the library to its normal state after a disaster. The main aspects to be addressed would be the repair of damaged items and the re-institution of services. The first aspect requires specialized techniques and, very often external facilities such as freeze and freeze-drying equipment. Five out of the twelve libraries surveyed indicated that they had facilities for the restoration of damaged materials. However, their capabilities were mostly limited to basic repairs and to the restoring of water-damaged materials. The restoration of fire-damaged materials is a difficult process and few people in the Greater Cape Metropolitan Area have acquired the skills and/or techniques to take on such tasks. The library with the most extensive facilities for the repair of disaster damaged materials was the South African Library, which had a well-equipped conservation laboratory. They were able to repair all paper-based materials, as well as photographic materials. Restoration, with the specialized skills and equipment that is required, it is suggested would be an obvious area where all libraries in a geographical region could engage in co-operative ventures.

From the above, it is clear that the situation regarding disaster management and planning in the Greater Cape Metropolitan Area varies considerably. The majority of the libraries investigated in this study. were lacking in formal disaster plans and were generally under-prepared for any potential disasters which may occur. Disaster routines, such as emergency drills, tended to be organized on an irregular, ad-hoc basis. However, where disaster plans did exist it was evident they were of a high standard and further that these libraries were well prepared in all aspects to prevent, contain and recover from a disaster. Three aspects, namely building maintenance inspections, computer back-up and fixed asset disaster insurance were generally well provided for by all the libraries.

One of the most surprising outcomes of the study was that most of the library systems that did not have formal disaster plans were of the larger and newer institutions in the Western Cape. It is accepted that financial and human resource constraints are a major inhibiting factor, and yet there was very 
little evidence that libraries have attempted to overcome this problem by engaging in co-operative disaster planning activities. It should be feasible to share expertise, skills, and facilities. It would further be advisable for the libraries in the Greater Cape Metropolitan Area to all institute disaster plans to ensure that they are adequately prepared for any emergency. The implementation of such plans could further be facilitated if all libraries could work together and learn to share resources.

Disaster management and planning in the Greater Cape Metropolitan Area would thus appear to be inadequate and this could be attributed, firstly, to inadequate financial and human resources, and, secondly, to the apathetic attitude on the part of library management and staff. Many libraries seem to adopt the attitude that 'it will never happen to us!'. It is further surmised that the situation regarding disaster management in the Greater Cape Metropolitan Area would probably prevail throughout South Africa (compare also the reports by Coates, 1987; 1993). The authors, therefore, hope that this article will prompt librarians to realize the importance of maintaining well-developed disaster management procedures that are based on a carefully formulated disaster plan.

In the following section a framework for a model disaster plan is outlined. It was developed by synthesizing data obtained from the empirical study reported above and information gleaned in the literature. It is further hoped that such a model would provide a framework to assist institutions in the practical aspects of disaster management, and in the development of disaster plans where such a lacuna exists, or in improving existing plans if required.

\section{Framework for a model disaster plan}

The following framework provides an outline of the general aspects that it is suggested should be included in a disaster plan. It is important to note that each library operates under different circumstances and conditions, and therefore, each library has different needs. Thus, the model disaster plan has not been developed to satisfy the specific needs of any particular library, but to provide general guidelines as to the format, content and layout of a disaster plan, which can be adapted to suit specific needs.

\section{General requirements and consideration}

It is essential that a disaster plan be formally developed, structured and documented. In the event of a disaster, people often tend to panic and forget even the most obvious and well rehearsed procedures (Fortson, 1992:84). It is, thus, important that the plan be well researched and relevant to the library's specific needs. The procedures laid out, should be concise, clear and simply explained. All staff should be aware of the existence of such a plan and the location of the copies. Disaster team members should be clearly designated, they should be well versed in the emergency procedures and have their own copies of the plan at hand at all times. Without being too lengthy or verbose, the plan should provide all the essential information needed to cope with the immediate reaction and recovery procedures (Ashman, 1995:11).

A further benefit of a written disaster plan is that the eventuality might arise that the staff member(s) who is (are) responsible for disaster reaction might not be available when a disaster does occur and the other staff member(s) present would then be able to take charge and follow procedures as outlined in the written plan. This would be very difficult to do without a written guideline. It is also essential to set up a disaster team, which would be responsible for the disaster planning process.

In the initial stages of the development of such a plan, experts in the field should be consulted, as well as libraries which have already developed their own disaster plans, and, those that have experienced a disaster(s) (Fortson, 1992:8486). Particularly in the South African context, where financial and staff resources are limited, co-operation between libraries in the sharing of both resources and skills, would be highly recommended.

\section{Main components of a disaster plan}

The following are considered to be the main components that a disaster plan should contain:

\section{List of personnel}

This section should include the names, addresses and telephone numbers of all the members of the disaster team. The leader of the team should be clearly indicated. The names, addresses and telephone numbers of all the staff who are willing to volunteer their services in the event of an emergency should further also be incorporated.

\section{Disaster reaction procedures}

This section must include:

- A summary of the reaction and evacuation procedures.

- Procedures for contacting disaster team members, and volunteer staff, if not already on site.

- Procedures for alerting emergency services, such as the fire department and external expert consultants.

- Reaction procedures relevant to different types of disasters. There should be a brief explanation about how to deal with different types of disasters. For example, in the event of a power failure, staff must know where the battery-operated equipment is stored and where the $U n$ interruptible Power Supply (UPS) is located.

- A floor plan indicating the location of fire extinguishers, emergency exits, and, gas-, water- and electricity main switches should be included.

- The location of disaster supplies must be indicated.

- Procedures for immediate disaster reaction must be explained.

- Procedures for determining further potential threats and assessing the stability of the building, before it can be entered safely to assess the damage. 
- Procedures for evacuating the materials to a safe, temporary storage area.

\section{Salvage and recovery procedures}

Once the material is in a safe storage area, prompt decisions must be taken regarding salvage procedures, according to the different types and extent of the damage. Swift reaction is important as, for example, in the event of water damage, mould will begin to grow within 48 hours. This section must, therefore, include the following guidelines:

- Each type of recovery procedure, for example freeze drying, vacuum-freeze drying, air drying, amongst others, should be briefly explained.

- Volunteers must be organized to help with the assessing and sorting of damaged materials.

- The damage must be assessed, preferably with the help of an expert, and the material must be sorted according to the different types of salvage procedures required. Guidelines should be provided for the assessing of damaged materials.

- The material that has to be sent to external contractors then has to be carefully packed into crates ready for transportation, for example, to freeze-drying or vacuum-drying facilities.

- Water damaged materials which can be air dried on site, must be placed in a safe storage area with the pages fanned out to facilitate drying.

- The building must be assessed to determine the extent of the damage and clearing up must begin as soon as possible.

- A decision would have to be taken concerning the possible closure of the library to the public during the clearing-up process, and possible re-opening dates would have to be announced.

\section{Equipment and supplies}

This section should include the following details:

- The location of disaster boxes, which should contain the materials immediately required for reaction procedures, as well as materials needed for the packing, securing and crating of damaged materials to the recovery section, or for transportation to external facilities.

- The contents of a disaster box which should consist, amongst others, of: plastic sheeting; scissors; un-printed newsprint; buckets; absorbent mops; large rubbish bins; large garbage bags; soft cloths; paper pads and pencils; heavy duty masking tape; plastic crates for transportation; weights; blotting paper; bookends; torches; sponges; wax paper; dust-cloths.

- Various kinds of equipment will also be necessary, and the location of this equipment must be indicated if available on the premises. Alternatively it must be stated from where each item can be hired, or otherwise obtained. The following are examples of equipment that might be required: wet and dry vacuum cleaners; hand- or battery operated water pumps; fire extinguishers; fans; dehumidifiers; water hoses.

- Protective clothing and first aid supplies must also be provided. In disaster areas where there is overflowing water or burst pipes, there is a very real danger of contamination due to leaking sewage. Cases have been reported where rescue workers have fallen ill due to such contamination. Items of protective clothing should include: waterproof aprons, overalls and pants; waterproof boots; rubber gloves; hard hats; a first aid box should be kept on the site, in case of cuts or burns.

\section{Priority materials}

This section should include:

- A clear indication of which important and/or rare materials should be evacuated first.

- The evacuation order must be clearly stated, if there are different categories of such materials.

- Floor plans indicating the location of these materials.

\section{Directory of external services and products}

A list of local providers of services and back-up facilities is an essential part of the disaster plan. Their names, addresses and phone numbers should be given. In each case a second contact name should be given in case the first is not available. The directory should include the following:

- Equipment hire places, freezing and transport services.

- Emergency services, such as the police and fire department.

- Disaster management experts, who have agreed to provide help and advice, when needed.

\section{Co-operative arrangements}

This section should include:

- The details of co-operative arrangements, which exist to share facilities and services in the event of an emergency.

- The nature and full details of the co-operative agreement must be indicated.

- The names and contact numbers of disaster managers at the other institutions must be given.

\section{Insurance}

This section should include:

- Details regarding insurance cover, claim procedures, and conditions of insurance.

- The adherence to insurance conditions is important, in order not to jeopardize the validity of possible claims. For example, the damaged premises might have to be inspected by an insurance agent, before anything is moved or any clearing up begins.

- Contact phone numbers of the insurance agent responsible. 


\section{Procedures for obtaining emergency funding}

Very often, in an emergency, ready cash is needed for various reasons, such as the purchasing of extra disaster supplies. Arrangements should be made to have access to contingency funds to meet such needs.

The following two sections should also be included in the disaster plan. They do not refer directly to emergency procedures, but are routine activities which should be conducted regularly as preventative measures.

\section{Arrangements for regular building inspections}

The method of inspection and the frequency between inspections should be indicated. If inspections are carried out by external contractors, then contact names and phone numbers should be provided.

\section{Arrangements for regular inspection of security equipment}

Facilities such as fire extinguishers and security alarms should be regularly inspected to ensure that they are in good working order. Details of the service contractor, contact names and phone numbers should be provided, as well as information regarding the optimum frequency of such inspections.

\section{Arrangements for regular emergency drills}

Routine emergency and evacuation drills are essential, both to ensure that staff are aware of procedures, and, that emergency procedures, exits and equipment such as fire alarms, are in working order. This section should include:

- The list of staff member(s) responsible for organizing emergency drills.

- Frequency of emergency drills.

- Details of the evacuation route, and the equipment and exits, which must be checked in the process.

\section{Appendices}

The appendices should include floor plans, indicating where priority materials are located, the location of emergency exits, security and safety equipment, and, the location of disaster boxes and equipment. Other items which can be included in the appendices are disaster reaction flow charts, damage lists and any other additional information that a specific library wishes to include.

\section{Conclusion}

In conclusion it can be stated that it is important that all libraries have a formal disaster plan and disaster management procedures. In order that this can be achieved, management in libraries should recognize that it is important in practice, and afford it more attention than it receives at present. Such a response will assist to dispel the apathetic attitude which exists with regard to disaster planning.

While it is recognized that financial and human resource constraints are a major prohibitive factor, this should not deter library management to be resourceful and to come up with innovative ways to institute disaster plans within the budget allocated. There is further very little evidence of efforts to overcome the cost and limited human resource factor by engaging in co-operative arrangements to share costs and resources. This is a particularly important consideration, as more than one library co-operative project is at present being planned in South Africa. Both skills and facilities can be shared in a co-operative effort to benefit all concerned. It is possible that emergency services, such as freeze and freezedrying facilities, temporary storage areas, as well as computer back-up facilities, can be shared to reduce costs. Restoration skills and techniques are very specialized, and these resources are available at only a few institutions in South Africa. These techniques and skills should be shared in the event of a disaster occurring.

To make librarians more aware of disaster management and planning, it is recommended that more opportunities for training be created, and that, if possible, workshops be organized to train librarians in the practical aspects of disaster management and planning. Training is also an expensive exercise, and the holding of co-operative workshops can reduce costs, and, knowledge and skills can be shared.

While the conceptual principles of disaster management are well developed internationally, particularly in Great Britain and the United States of America, the practical implementation of disaster management and planning has generally been sorely neglected. In South Africa both the theoretical issues and practical implementation have generally been overlooked. It is thus hoped that, in future, both the conceptual and practical development of this essential field of management will receive the required recognition by library managers and that the above-stated recommendations and framework for a model will serve as a basis for further research and development in this field.

Finally we would like to concur with Buchanan (1988:7) that

'A written plan is the single most important step in preparing for disasters. First, such a written document acknowledges that disasters are possible and that there is a commitment on the part of the organisation to accept responsibility in a sensible and logical way. Second, preparation and a written plan eliminates panic, assures proper decisions, reduces the damage to collections and limits the cost of recovery. Third, a plan consolidates ideas and provides step-by-step instructions which are clear and easy to follow for anyone who is called upon to use them'.

\section{Acknowledgements}

This article is based on research conducted at the School of Librarianship, University of Cape Town in partial fulfilment of the requirements for the degree of Master of Librarianship. 


\section{References}

ALEGBELEYE, B. 1993. Disaster control planning for libraries, archives and electronic data processing centres in Africa. Ibadan: Options Book and Information Services.

ANDERSON, H. \& MCINTYRE, J.E. 1985. Planning manual for disaster control in Scottish libraries and record offices. Edinburgh: National Library of Scotland.

ASHMAN, J. 1995. Disaster planning for library and information services. London: Aslib.

BOHEM, H. 1979. Regional conservation services: what can we do for ourselves? Library journal, 104(13):1428-1431.

BUCHANAN, S. 1979. The Stanford Library flood restoration project. College and research libraries, 40(6):539-548.

BUCHANAN, S. 1988. Disaster planning: preparedness and recovery for libraries and archives, a RAMP study with guidelines. Paris: Unesco.

BURGESS, D. 1989. The library has blown up! Library journal, 114(16):59-61.

CHAMBERS twentieth century dictionary. (rev. ed.) 1972. Edinburgh: Chambers.

COATES, P.R. 1987. Planning for disaster control. In Books in peril: proceedings of the symposium on the preservation of library and archival materials in Southern Africa held at the South African Library, Cape Town, 19-21 November 1986. Cape Town: The South African Library, 51-61.

COATES, P.R. 1993. Preservation in South Africa: the present situation. International preservation news, (6):9-11.

DECANDIDO, G.A. 1988. Special report: fire at the USSR Academy of Sciences Library. Library journal, 113(1):10-12.

DONELLY, H. 1993. Disaster planning in the 90s: getting it right. Conservation administration news, (52):10-11.

FORTSON, J. 1992. Disaster planning and recovery: a how-to-do-it manual for librarians and archivists. New York: Neal-Schuman.

GRIFFITH, J.W. 1983. After the disaster: restoring the library service. Wilson library bulletin, 58(4):258-265.

HARRISON, A.W. 1979. Conservation of library materials: clip no. 9. ALA bulletin, 43(1):7.
HARVEY, R. 1993a. Preservation in libraries: a reader. London: Bowker.

HARVEY, R. 1993b. Preservation in libraries: principles, strategies and practices for librarians. London: Bowker.

KAHN, M. 1994. Fires, earthquakes, and floods. Online, 18(3):1924.

MCINTYRE, J.E. 1988. Disaster control planning. Serials, 1(2):4246.

MCINTYRE, J.E. 1989. Action planning for disaster. Refer, 5(4): 17.

MORRIS, J. 1986. The library disaster preparedness handbook. Chicago: American Library Association.

NANCE, W. 1993. Issues in disaster preparedness for information and referral providers. Information and referral, (15):63-71.

OLSON, N.B. 1986. Having your software out to dry. College and research library news, 47(10):653-636.

PARSONS, E.A. 1952. The Alexandrian library: glory of the Hellenistic world, its rise, antiquities and destruction. Amsterdam: Elsevier.

SCHMELZER, M. 1968. Fire and water: book salvage in New York and Florence. Special libraries, 59(8):620-625.

SOUTH AFRICAN OFFICIAL YEARBOOK (18th ed.) 1992. Pretoria: Government Printer.

STRONG, G.E. 1987. Rats, oh no, not rats! Special libraries, 78(2):105-111.

SUNG, C. H., LEONOV, V. P. \& WATERS, P. 1990. Fire recovery at the library of the Academy of Sciences of the USSR. American archivist, 53(2):298-312.

THORBURN, G. 1993. Library fire and flood: successful salvage, but beware of the cowboy. Aslib information, 21(2):76-78.

WATSON, T. 1989. Out of the ashes: the Los Angeles Public Library. Wilson library bulletin, December:34-41.

WATTS, A. 1993. Disaster planning and management. Inform, (156):5.

WRIGHT, G.H. 1979. Fire! Anguish! Dumb luck! Or contingency planning. Canadian library journal, 36(5):254-260. 